\title{
Gastrointestinal Adverse Events of Cannabinoid 1 Receptor Inverse Agonists suggest their Potential Use in Irritable Bowel Syndrome with Constipation: A Systematic Review and Meta-Analysis
}

\author{
Adam Fabisiak $^{1,2}$, Marcin Włodarczyk ${ }^{1,3}$, Natalia Fabisiak ${ }^{1,4}$, Martin Storr $^{5,6}$, Jakub Fichna ${ }^{1}$
}

1) Department of

Biochemistry, Faculty of

Medicine, Medical University

of Lodz, Lodz; Poland

2) Department of Digestive

Tract Diseases, Faculty of

Medicine, Medical University

of Lodz, Lodz, Poland

3) Department of General and Colorectal Surgery, Faculty of Military Medicine, Medical University of Lodz, Poland

4) Department of

Gastroenterology, Faculty of

Military Medicine, Medical

University of Lodz, Poland

5) Center of Endoscopy,

Starnberg, Germany

6) Department of Medicine

II, Ludwig Maximilians

University of Munich,

Germany

Address for correspondence: Prof. Jakub Fichna, PhD, DSc, Department of Biochemistry, Faculty of Medicine,

Medical University of Lodz, Mazowiecka 6/8, 92-215 Lodz, Poland

jakub.fichna@umed.lodz.pl

Received: 10.07.2019 Accepted: 10.11.2019

\section{ABSTRACT}

Background \& Aims: Irritable bowel syndrome (IBS) is one of the most common functional gastrointestinal (GI) disorders characterized by pain and impaired bowel movements. Currently available drugs show limited efficacy. Cannabinoid 1 receptor (CB1) inverse agonists (CB1-RAN) cause diarrhea and may be candidates for the treatment of constipation-predominant IBS (IBS-C). We evaluated the effects of CB1-RAN in clinical trials for their potential use in IBS-C.

Methods: Database search identified all clinical trials published up to May 2018 that reported rimonabant and taranabant treatment for at least one month and detailed the GI adverse events (AEs). Categorical outcomes (subgroups of AEs) were analyzed using the odds ratio (OR).

Results: Eighteen trials met the inclusion criteria. Rimonabant $20 \mathrm{mg}$ produced significantly more overall AEs (OR=1.35, CI: 1.19-1.52, p<0.0001), psychiatric events (OR=1.79, CI: $1.46-2.21, \mathrm{p}<0.001)$ and GI AEs ( $\mathrm{OR}=2.05$, CI: $1.65-2.55, \mathrm{p}<0.001)$ compared to placebo. Taranabant at doses ranging from 0.5 to 8 mg produced significantly more overall AEs $(\mathrm{OR}=1.36$, CI: $1.13-1.64, \mathrm{p}<0.002)$, psychiatric AEs (1.82, CI: 1.54-2.16, $\mathrm{p}<0.001)$ and GI AEs (OR=1.75, CI: 1.29-2.37, $\mathrm{p}<0.001)$ compared to placebo.

Conclusions: The approach to target $\mathrm{CB} 1$ in the gut for the treatment of IBS- $\mathrm{C}$ or chronic constipation seems a promising therapeutic option. Prospective clinical trials on the possible targeting of CB1 and the endocannabinoid system are warranted.

Key words: irritable bowel syndrome - cannabinoid 1 receptor inverse agonists - rimonabant - taranabant.

Abbreviations: AE: adverse event; CB: cannabinoid receptor; CB1-RAN: cannabinoid 1 receptor inverse agonists; GI: gastrointestinal; IBS: irritable bowel syndrome; IBS-C: constipation predominant IBS; IBS-D: diarrhea predominant IBS; IBS-M: alternating/mixed IBS; OTC: over the counter; RCT: randomized controlled trial; TEAE treatment emerged AE.

\section{INTRODUCTION}

Irritable bowel syndrome (IBS) is the most common functional gastrointestinal (GI) disorder characterized by abdominal pain and changes in bowel habits. Different subtypes of IBS are most prevalent: constipation predominant (IBS-C), diarrhea predominant (IBS-D) and alternating/ mixed IBS (IBS-M). A recent meta-analysis estimated global prevalence of IBS at $11.2 \%$ [1]. However, the actual prevalence varies in different countries and in the diagnostic criteria used. Also, owing to the fact that a group of patients with milder symptoms do not report their signs to the physician, the overall prevalence of IBS may be much higher.

Diagnosis of IBS is based on symptoms and, according to Rome IV criteria [2], entails recurrent abdominal pain occurring at least one day a week on average during the preceding three months, associated with at least two of the following: pain related to defecation, changes in defecation or bowel habits or changes in stool consistency. Currently available drugs are of limited value and future potent drugs are urgently needed [3]. Chronic constipation is diagnosed based on exclusion of any organic disease.

In IBS-C, over-the-counter (OTC) drugs such as osmotic or stimulant laxatives, fiber, and prokinetics are used for first-line therapy, but a large proportion of patients remain symptomatic. Newer pharmacological agents such as lubiprostone, 
methylnaltrexone, prucalopride, linaclotide and naloxegol exhibit superiority to placebo in relieving constipation, but they are not free of adverse events (AEs) such as abdominal pain or diarrhea [4]. Recently, cannabinoid receptor (CB) inverse agonists have become potential candidates for treatment of IBS-C. In line, our group has shown that taranabant, a CB1 inverse agonist (CB1RAN) increased intestinal transit in preclinical studies [5].

Taranabant, along with rimonabant has been tested in numerous clinical trials as potential anti-obesity drugs with good efficacy. Although rimonabant was withdrawn from the market and phase III trials with taranabant were terminated due to serious psychiatric AEs [6], the approach to block $\mathrm{CB}$ receptors in GI pathologies with constipation remains open. For instance, alleles polymorphisms in the CB1 gene (CNR1) were found to be significantly associated with IBS in Korean population [7]. Also, patients with IBS exerted changes in plasma levels of certain endogenous cannabinoids such as anandamide, 2-arachidonyloglycerol (2-AG), oleoylethanolamide and palmitoylethanolamide as presented in a study by Fichna et al. [8]. Furthermore, mRNA level of fatty acid amide hydrolase was lower in patients with IBS-D. Finally, CB agonist dronabinol reduced colonic motility in healthy human volunteers in a randomized, placebo-controlled study [9]. All the above support the potential implication of an endogenous cannabinoid system in regulating bowel movements and imply that peripherally restricted drugs without central side effects may be an option in the treatment of constipation issues.

In this systematic review and meta-analysis, we assessed AEs of rimonabant and taranabant from the available randomized clinical studies to evaluate their potential use in IBS-C. By focusing our meta-analysis on GI effects of nonselective CB1-RAN, we set the stage for further research of more selective compounds.

\section{METHOD}

\section{Inclusion/exclusion criteria and extracted data}

All clinical randomized controlled trials (RCTs) that included rimonabant and taranabant (at any dosage) treatment for at least one month and reported any GI side effects for both, treatment and placebo groups were considered. Studies published in abstract form were eligible if sufficient data were provided to assess the quality of the study and reported outcomes. RCTs with patients in an active treatment arm receiving rimonabant or taranabant compared to a control arm of patients receiving placebo or another active therapy were appraised for inclusion. There were no exclusions based on the type and dose of the rimonabant or taranabant intervention. Studies were excluded if: (i) they were review articles, (ii) they were drug comparison studies (iii) the study lasted for less than one month, (iv) the study assessed the single dose regimen. For each included study, two investigators independently extracted the essential information: the name of the first author, year of publication, number of participants (patients and controls), dose of studied drug, duration of the therapy and specific AEs: GI, psychiatric, neurological, cardiac, vascular and overall reported events. A few authors were asked for missing data, which were required in this review.
The outcomes that we analyzed were categorized as: any AEs, any GI AEs (nausea, vomiting and diarrhea), discontinuation due to GI event, any psychiatric $\mathrm{AE}$, any other (cardiovascular, neurologic) AE.

\section{Literature search strategy}

The following electronic databases were searched: MEDLINE (January 2000 to December 2017, EMBASE (January 2000 to December 2017), Cochrane Central Register of Controlled Trials (2000-2017), ongoing trials were identified from the registry http://ClinicalTrials.gov. A manual search of reference lists of studies and review articles was performed. The following search terms were used: ("Rimonabant" OR "Taranabant") in combination with filters: "Randomized Controlled Trial"; "Human"; respective years considered. The search was complemented by a manual search of the bases. The final set from each search was combined and reviewed for duplications.

\section{Study selection}

All identified citations were reviewed independently by two authors (M.S. and A.F.) to screen for potential trials to be included in the final review. The authors (M.S. and A.F.) independently assessed the full text articles of all potentially relevant trials. Articles that were published in abstract form only were considered if sufficient details were provided to assess the methodology and reported outcomes. Any disagreement was resolved through discussion and consensus. The risk of bias of individual study was assessed by A.F. and M.W. using the following components: randomization process, deviations from intended interventions, incomplete outcome data, measurement of the outcome, selection of the reported results [10]. Any disagreements were resolved by discussion.

\section{Data analysis}

The calculations were performed with the use of Statistica version 13.0 with the Analytical Toolkit for meta-analysis and meta-regression (Statsoft, Inc., Tulsa, OK, USA; Statsoft Polska, Krakow, Poland). We calculated dichotomous variables using an estimation of odds ratio (OR) with $95 \%$ confidence interval (CI). We used a random effect model because the involved studies were drawn from populations that differ from each other in ways that could impact on the treatment effect. A p value less than 0.05 was considered as statistically significant. Study heterogeneity was determined using the $\mathrm{I}^{2}$ statistic (the variability in the effect results from heterogeneity rather than sampling error) and the Q-statistic ( $\mathrm{p}<0.05$ was considered significant and suggested statistical heterogeneity). $\mathrm{I}^{2}>50 \%$ and $\mathrm{I}^{2}<25 \%$ indicate large and small inconsistency, respectively [11]. Due to the limitation and potential misleading information from the funnel plots reported in literature, we did not use them to assess for publication bias in this review [12].

\section{RESULTS}

\section{Basic description of the search}

The study selection process is shown in Fig. 1. A total of 232 records were found through an initial search of the databases from which 214 were excluded. In total, 18 studies fulfilled 


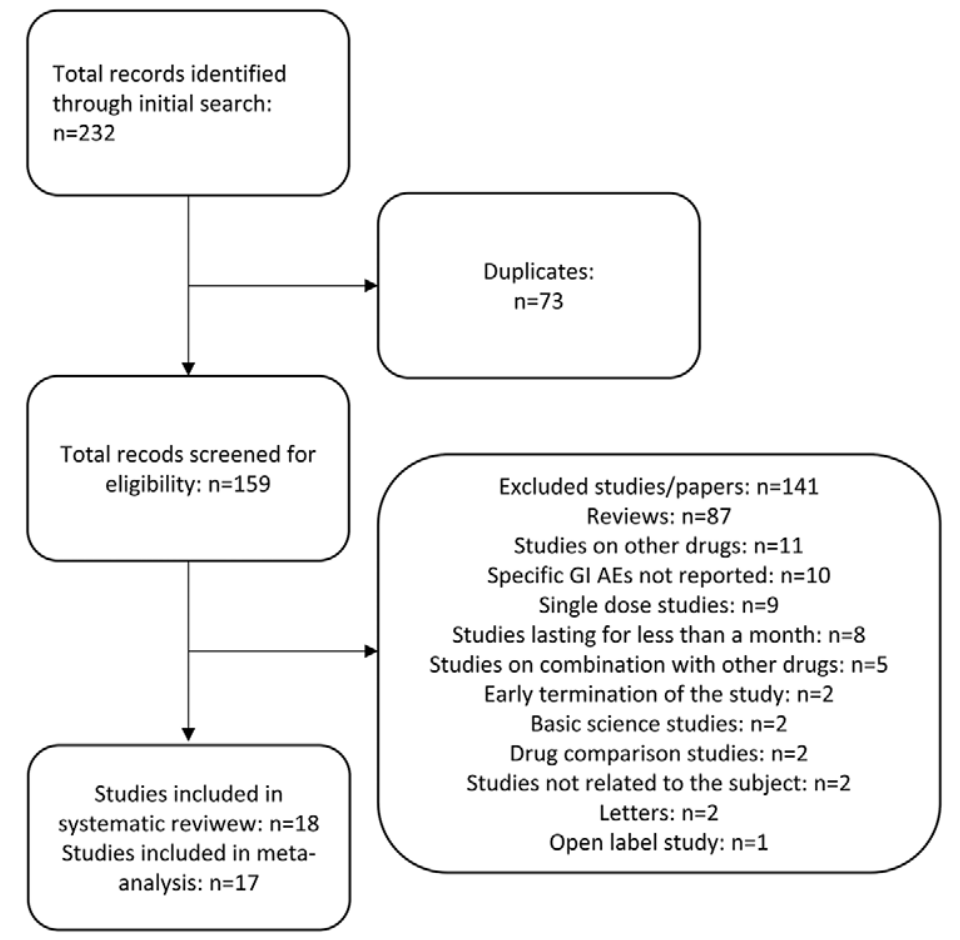

Fig. 1. Process of literature search, selection and exclusion.

our inclusion criteria [13-30]. The basic characteristics of the included studies are described in Table I. Two doses of rimonabant were repeatedly reported in the studies: 5 or $20 \mathrm{mg}$; taranabant was sparsely administered in doses ranging from 0.5 to $8 \mathrm{mg}$. All studies were of at least acceptable quality, five studies were appraised as 'questionable quality', and no high risk of bias were noticed (Fig. 2). Authors agreed to implement the five mentioned studies in the meta-analysis. Also, pooled analysis of unpublished data from three studies was included [16]. Authors decided to exclude one large study [31] due to the premature discontinuation of this trial.

Nine studies assessed the efficacy of CB1-RAN to induce weight change [13-15, 17, 24-27, 29], two trials searched the efficacy of CB1-RAN to change hemoglobin A1c level [20, 22], one study assessed both these features [28], two studies addressed the efficacy of CB1-RAN in smoking cessation [16, 30]. Some effects were studied each one in one trial: atheroma reduction [18], alcohol dependence [19], change in lipid profile [21] and carotid intima-media thickness [23]. Two papers described the same study (RIO-Europe) and assessed the efficacy of rimonabant to induce weight change over the period of 1 year [32] and after 2 years [17]. We decided to include only the results of the latter, because the same population was included in both studies.

\section{Safety}

\section{Overall adverse events}

In our meta-analysis, a total of 3038 patients received $5 \mathrm{mg}$ of rimonabant vs 2391 patients in the placebo group, in 5035 patients were administered $20 \mathrm{mg}$ rimonabant vs 4138 patients in the placebo group, and 3300 patients received any dose of taranabant vs 1239 patients in the placebo group.

Overall, OR for producing any AEs for rimonabant $5 \mathrm{mg}$ was not significantly higher compared with placebo $(\mathrm{OR}=1.04$,

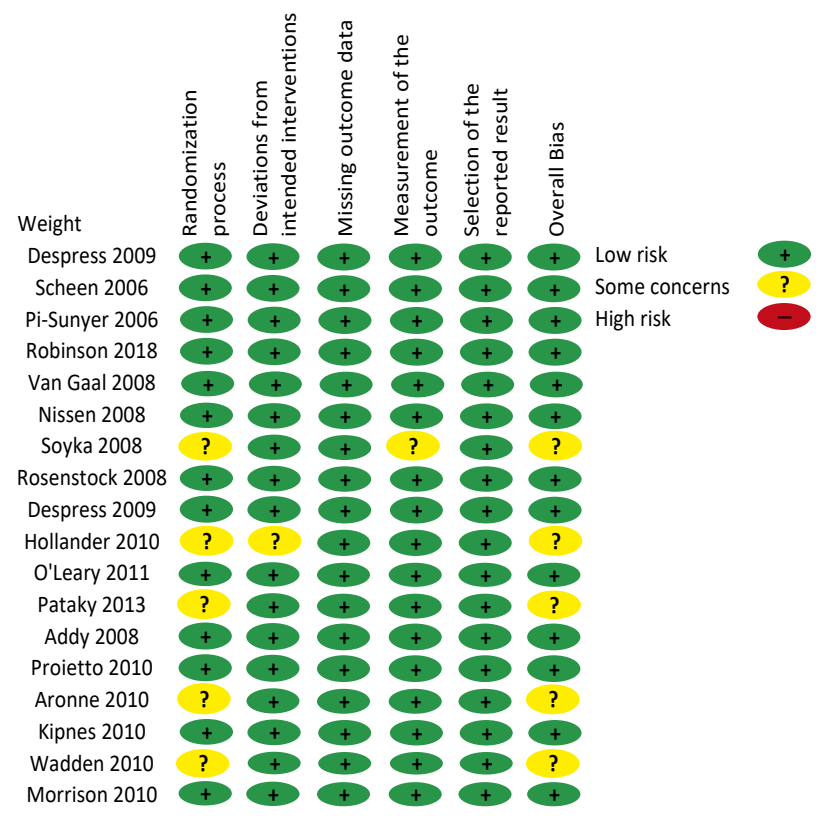

Fig. 2. Risk of bias.

CI: $0.91-1.19, \mathrm{p}=0.52$, Fig. $3 \mathrm{~A})$. Conversely, patients treated with $20 \mathrm{mg}$ of rimonabant produced significantly more AEs compared with a placebo $(\mathrm{OR}=1.35$, CI: $1.19-1.52, \mathrm{p}<0.0001$, Fig. 4A). Taranabant at any dose produced significantly more AEs compared with a placebo $(\mathrm{OR}=1.36, \mathrm{CI}: 1.13-1.64, \mathrm{p}<$ 0.002, Fig. 5A).

\section{Psychiatric adverse events}

Psychiatric AEs in patients taking $5 \mathrm{mg}$ of rimonabant occurred non-significantly more often in the treated group compared to placebo $(\mathrm{OR}=1.05, \mathrm{CI}: 0.88-1.24, \mathrm{p}=0.59$, Fig. 
Table I. Basic characteristics of the studies included in the meta-analysis, provided with the Jadad score.

\begin{tabular}{|c|c|c|c|c|c|c|c|}
\hline $\begin{array}{l}\text { Authors (Year) } \\
{[\text { Ref \#] }}\end{array}$ & $\begin{array}{l}\text { Numbers of subjects } \\
\text { studied }\end{array}$ & $\begin{array}{l}\text { Length } \\
\text { (weeks) }\end{array}$ & Primary outcome & $\begin{array}{l}\text { Double- } \\
\text { blinding }\end{array}$ & $\begin{array}{l}\text { Randomization } \\
\text { and concealment } \\
\text { of allocation }\end{array}$ & $\begin{array}{l}\text { Description of } \\
\text { withdrawals } \\
\text { and dropouts }\end{array}$ & $\begin{array}{l}\text { Jadad } \\
\text { score }\end{array}$ \\
\hline $\begin{array}{l}\text { Després (2005) } \\
{[13]}\end{array}$ & $\begin{array}{l}\text { Placebo }=342 \\
\text { Rimonabant } 5 \mathrm{mg}=345\end{array}$ & 12 & Weight change & Yes & Described & Yes & 5 \\
\hline $\begin{array}{l}\text { Scheen (2006) } \\
{[14]}\end{array}$ & $\begin{array}{l}\text { Placebo }=348 \\
\text { Rimonabant } 5 \mathrm{mg}=358 \\
\text { Rimonabant } 20 \mathrm{mg}=339\end{array}$ & 48 & Weight change & Yes & Described & Yes & 5 \\
\hline $\begin{array}{l}\text { Pi-Sunyer } \\
(2006)[15]\end{array}$ & $\begin{array}{l}\text { Placebo }=607 \\
\text { Rimonabant } 5 \mathrm{mg}=1214 \\
\text { Rimonabant } 20 \mathrm{mg}=1219\end{array}$ & 48 & Weight change & Yes & Described & Yes & 5 \\
\hline $\begin{array}{l}\text { Robinson } \\
\text { (2006) [16] }\end{array}$ & $\begin{array}{l}\text { Placebo }=789 \\
\text { Rimonabant } 5 \mathrm{mg}=518 \\
\text { Rimonabant } 20 \mathrm{mg}=790\end{array}$ & 48 & Smoking abstinence & Yes & Described & No & 3 \\
\hline $\begin{array}{l}\text { Van Gaal } \\
(2008)[17]\end{array}$ & $\begin{array}{l}\text { Placebo }=168 \\
\text { Rimonabant } 5 \mathrm{mg}=363 \\
\text { Rimonabant } 20 \mathrm{mg}=355\end{array}$ & 96 & Weight change & Yes & Described & Yes & 5 \\
\hline $\begin{array}{l}\text { Nissen (2008) } \\
{[18]}\end{array}$ & $\begin{array}{l}\text { Placebo }=417 \\
\text { Rimonabant } 20 \mathrm{mg}=422\end{array}$ & 72 & $\begin{array}{l}\text { Change in the percentage of } \\
\text { atheroma volume }\end{array}$ & Yes & Described & Yes & 5 \\
\hline $\begin{array}{l}\text { Soyka (2008) } \\
{[19]}\end{array}$ & $\begin{array}{l}\text { Placebo }=127 \\
\text { Rimonabant } 20 \mathrm{mg}=131\end{array}$ & 12 & $\begin{array}{l}\text { Time to first drink and the time to } \\
\text { relapse to first heavy drinking }\end{array}$ & Yes & Not described & Yes & 3 \\
\hline $\begin{array}{l}\text { Rosenstock } \\
(2008)[20]\end{array}$ & $\begin{array}{l}\text { Placebo }=140 \\
\text { Rimonabant } 20 \mathrm{mg}=138\end{array}$ & 24 & Hemoglobin A1C change & Yes & Described & Yes & 5 \\
\hline $\begin{array}{l}\text { Després (2009) } \\
{[21]}\end{array}$ & $\begin{array}{l}\text { Placebo }=395 \\
\text { Rimonabant } 20 \mathrm{mg}=404\end{array}$ & 48 & $\begin{array}{l}\text { Change in HDL-C and } \\
\text { triglyceride }\end{array}$ & Yes & Described & Yes & 5 \\
\hline $\begin{array}{l}\text { Hollander } \\
(2010)[22]\end{array}$ & $\begin{array}{l}\text { Placebo = } 179 \\
\text { Rimonabant } 20 \mathrm{mg}=187\end{array}$ & 48 & Hemoglobin A1C change & Yes & Described & No & 4 \\
\hline $\begin{array}{l}\text { O’Leary (2011) } \\
{[23]}\end{array}$ & $\begin{array}{l}\text { Placebo }=335 \\
\text { Rimonabant } 20 \mathrm{mg}=325\end{array}$ & 30 & $\begin{array}{l}\text { Absolute change in averaged per } \\
\text { patient carotid intima-media } \\
\text { thickness }\end{array}$ & Yes & Described & Yes & 5 \\
\hline $\begin{array}{l}\text { Pataky (2013) } \\
{[24]}\end{array}$ & $\begin{array}{l}\text { Placebo }=146 \\
\text { Rimonabant } 20 \mathrm{mg}=143\end{array}$ & 48 & Weight change & Yes & Described & Yes & 5 \\
\hline $\begin{array}{l}\text { Addy (2008) } \\
{[25]}\end{array}$ & $\begin{array}{l}\text { Placebo }=105 \\
\text { Taranabant } 0.5 \mathrm{mg}=106 \\
\text { Taranabant } 2 \mathrm{mg}=109 \\
\text { Taranabant } 4 \mathrm{mg}=105 \\
\text { Taranabant } 6 \mathrm{mg}=108\end{array}$ & 12 & Weight change & Yes & Described & Yes & 5 \\
\hline $\begin{array}{l}\text { Proietto (2010) } \\
{[26]}\end{array}$ & $\begin{array}{l}\text { Placebo }=209 \\
\text { Taranabant } 0.5 \mathrm{mg}=207 \\
\text { Taranabant } 1 \mathrm{mg}=208 \\
\text { Taranabant } 2 \mathrm{mg}=417\end{array}$ & 52 & Weight change & Yes & Described & Yes & 5 \\
\hline $\begin{array}{l}\text { Aronne (2010) } \\
{[27]}\end{array}$ & $\begin{array}{l}\text { Placebo }=417 \\
\text { Taranabant } 6 \mathrm{mg}=414 \\
\text { Taranabant } 4 \mathrm{mg}=415\end{array}$ & 104 & Weight change & Yes & Unclear & Yes & 4 \\
\hline $\begin{array}{l}\text { Kipnes (2010) } \\
{[28]}\end{array}$ & $\begin{array}{l}\text { Placebo }=156 \\
\text { Taranabant } 0.5 \mathrm{mg}=155 \\
\text { Taranabant } 1 \mathrm{mg}=157 \\
\text { Taranabant } 2 \mathrm{mg}=154\end{array}$ & 52 & $\begin{array}{l}\text { Change in body weight and } \\
\text { Hemoglobin Alc }\end{array}$ & Yes & Unclear & Yes & 4 \\
\hline $\begin{array}{l}\text { Wadden (2010) } \\
\text { [29] }\end{array}$ & $\begin{array}{l}\text { Placebo }=194 \\
\text { Taranabant } 0.5 \mathrm{mg}=195 \\
\text { Taranabant } 1 \mathrm{mg}=196 \\
\text { Taranabant } 2 \mathrm{mg}=195\end{array}$ & 63 & Weight change & Yes & Not described & No & 3 \\
\hline $\begin{array}{l}\text { Morrison } \\
(2010)[30]\end{array}$ & $\begin{array}{l}\text { Placebo }=158 \\
\text { Taranabant } 2-8 \mathrm{mg}=159\end{array}$ & 8 & Smoking abstinence & Yes & Described & Yes & 5 \\
\hline
\end{tabular}

3B). The dose of $20 \mathrm{mg}$ of rimonabant produced significantly more psychiatric AEs than placebo $(\mathrm{OR}=1.79$, CI: $1.46-$ 2.21, $\mathrm{p}<0.001$, Fig. 4B). Taranabant at any dose produced significantly more psychiatric AEs than placebo $(\mathrm{OR}=1.82$, CI: 1.54-2.16, p<0.001, Fig. 5B).

\section{Gastrointestinal adverse events}

Overall GI AEs were non-significantly more frequently reported in patients treated with $5 \mathrm{mg}$ of rimonabant compared to a placebo $(\mathrm{OR}=1.14$, CI: $0.95-1.37, \mathrm{p}=0.16$, Fig. $3 \mathrm{C})$. Similarly, specific GI AEs were not-significantly higher in the 

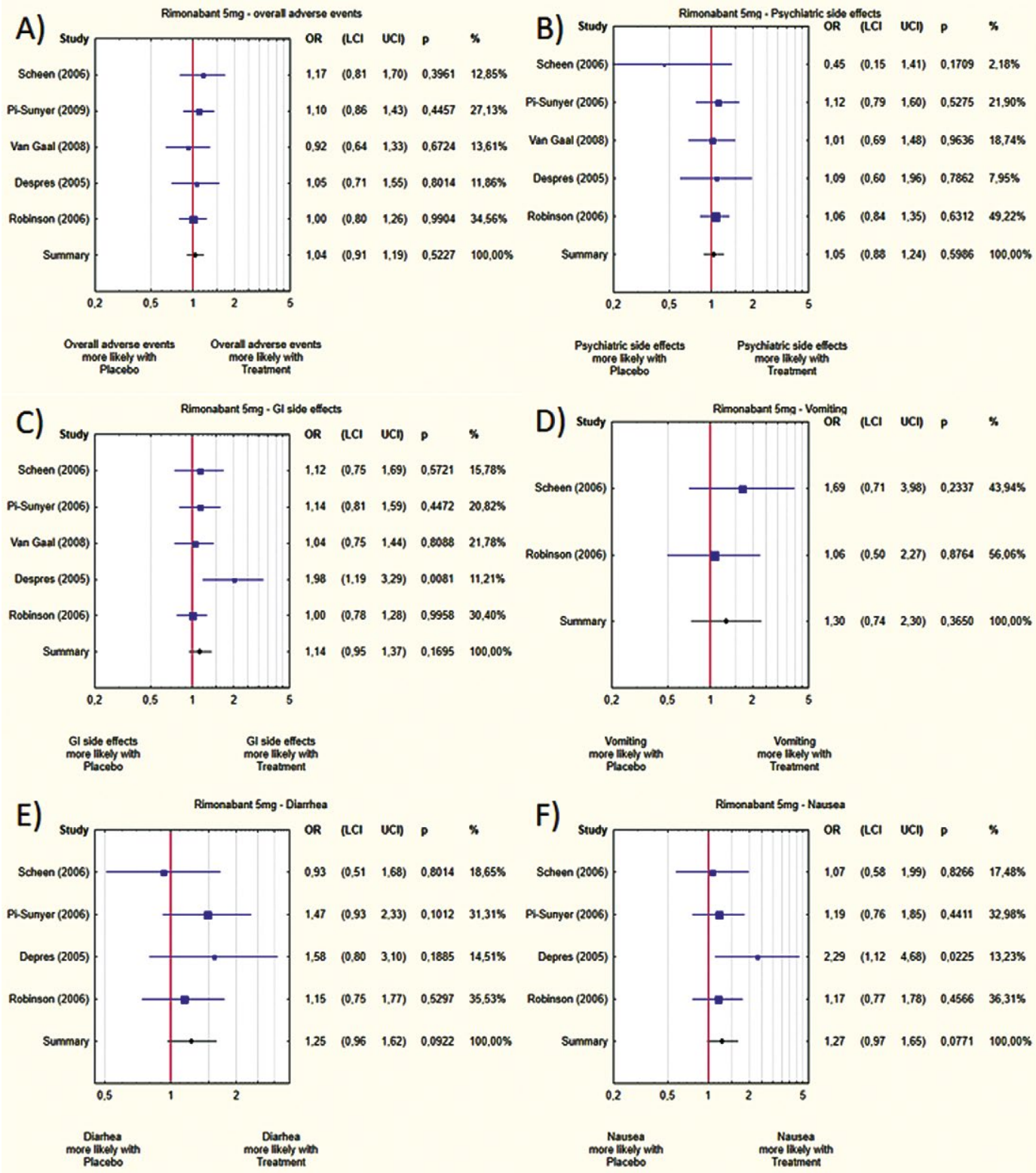

Fig. 3. Forest plots of adverse events reported in studies with rimonabant $5 \mathrm{mg}$ vs. placebo. A) overall AEs, B) psychiatric AEs, C) GI AEs, D) diarrhea, E) nausea, F) vomiting. OR: odds ratio, LCI and UCI: lower and upper confidence interval

rimonabant $5 \mathrm{mg}$ treated group compared to placebo: diarrhea $(\mathrm{OR}=1.25$, CI: $0.96-1.62$, $\mathrm{p}=0.09$, Fig. 3D), nausea $(\mathrm{OR}=1.27$, CI: $0.97-1.65, \mathrm{p}=0.07$, Fig. $3 \mathrm{E})$ and vomiting $(\mathrm{OR}=1.30, \mathrm{CI}$ : $0.74-2.30, \mathrm{p}=0.35$, Fig $3 \mathrm{~F})$.

Rimonabant in a dose of $20 \mathrm{mg}$ produced significantly more GI AEs than a placebo (OR=2.05, CI: $1.65-2.55, \mathrm{p}<0.001$, Fig. $4 \mathrm{C})$. Accordingly, specific GI AEs were more frequent in the treated group compared to a placebo: diarrhea $(\mathrm{OR}=1.51, \mathrm{CI}$ : $1.25-1.81, \mathrm{p}<0.001$, Fig. $4 \mathrm{D})$, nausea $(\mathrm{OR}=2.95, \mathrm{CI}: 1.81-4.67$, $\mathrm{p}<0.001$, Fig. $4 \mathrm{E})$ and vomiting $(\mathrm{OR}=2.54$, CI: $1.82-3.54$, $\mathrm{p}<0.001$, Fig. 4F).

Taranabant at any dose produced significantly more overall GI AEs compared to the placebo group $(\mathrm{OR}=1.75, \mathrm{CI}$ : 1.29-2.37, p<0.001, Fig. 5C). A similar pattern was observed for specific GI AEs. Patients treated with taranabant at any dose had diarrhea significantly more often $(\mathrm{OR}=1.94, \mathrm{CI}$ : 1.49-2.52, $\mathrm{p}<0.001$, Fig. 5D), nausea (OR=3.17, CI: 1.98-2.05, $\mathrm{p}<0.001$,
Fig. 5E) and vomiting (OR=2.54, CI: 1.82-3.54, p<0.001, Fig. $5 \mathrm{~F})$ compared to a placebo.

\section{Other adverse events}

Additional forest plots comparing the neurological, cardiac and vascular side effects in treated groups and placebo can be found in supplementary files. These AEs were non-significantly more common in rimonabant $20 \mathrm{mg}(\mathrm{OR}=1.15$, CI: 0.95-1.40, $\mathrm{p}=0.15)$ and taranabant $(\mathrm{OR}=1.18, \mathrm{CI}: 0.88-1.58, \mathrm{p}=0.25)$ groups when compared to placebo. Interestingly, patients taking rimonabant $5 \mathrm{mg}$ presented non-significantly fewer AEs when compared to a placebo $(\mathrm{OR}=0.96, \mathrm{CI}: 0.78-1.20, \mathrm{p}=0.73)$.

\section{DISCUSSION}

In several clinical RCTs the CB1-RAN, rimonabant and taranabant were shown to exert significantly more AEs 

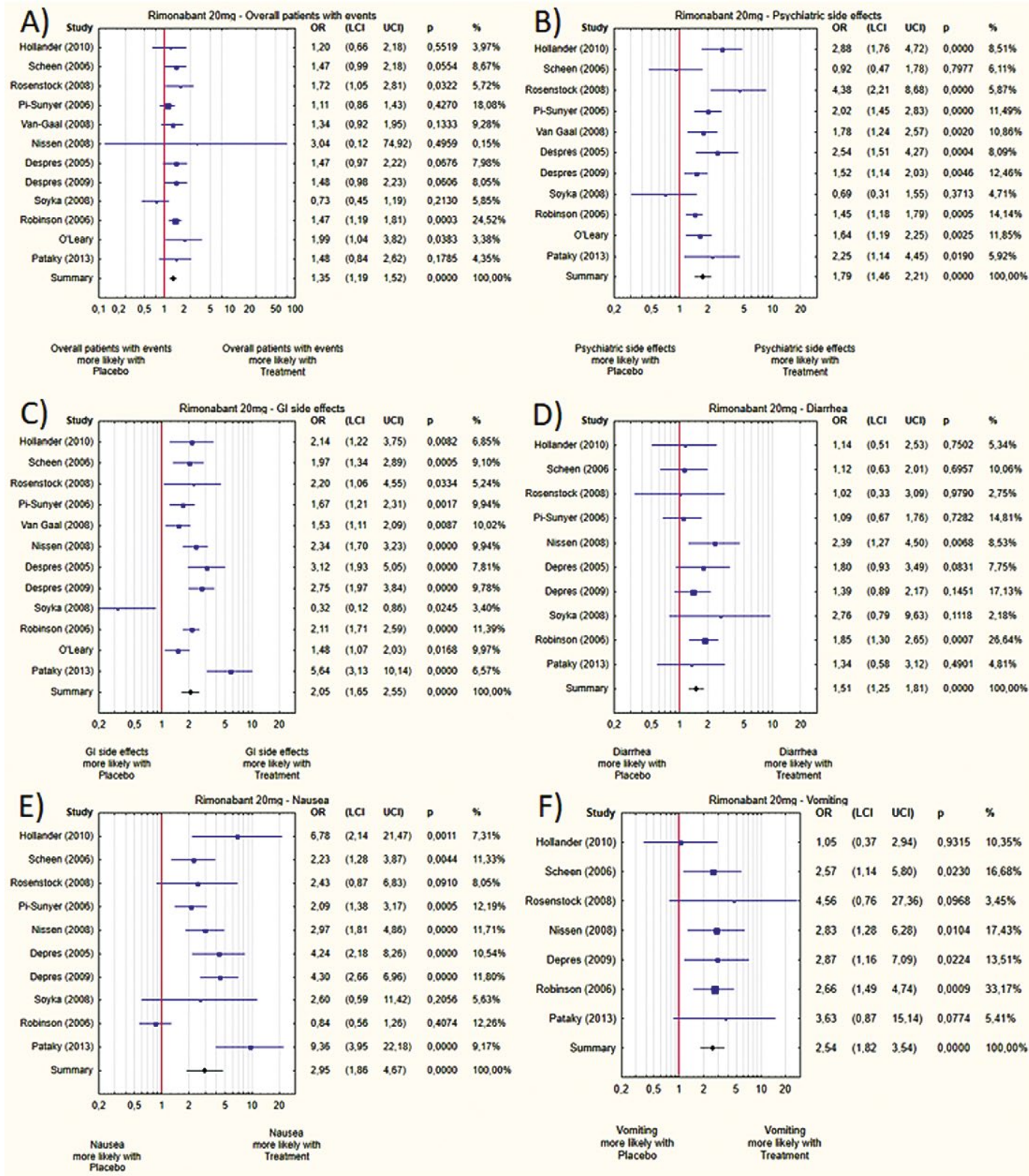

Fig. 4. Forest plots of adverse events reported in studies with rimonabant $20 \mathrm{mg}$ vs. placebo. A) overall AEs, B) psychiatric AEs, C) GI AEs, D) diarrhea, E) nausea, F) vomiting. OR: odds ratio, LCI and UCI: lower and upper confidence interval.

compared to a placebo. In our study, we analyzed the specific GI events for both compounds, reported in RCTs in light of their potential use for the treatment of constipation. The rationale for this was that in preclinical studies CB1-RAN increase GImotility and GI transit [5]. However, despite the promising results in animal studies, no human RCT supports our thesis. The results of the present meta-analysis indicate that patients treated with rimonabant or taranabant experienced more GI AEs such as diarrhea, nausea, vomiting compared to a placebo and that this effect was dose-dependent.

Cannabinoid receptors 1 are mostly expressed throughout the central and peripheral nervous system but they were also found in several other organs such as liver or GI epithelial cells [33]. Activation of CB1 inhibits GI transit through peripheral and central receptors [34]. The CB1-RAN rimonabant and taranabant exerted great efficacy in reducing weight in clinical trials. However, the phase III studies were suspended and rimonabant was eventually withdrawn from the market due to the serious psychiatric AEs including depression and suicidal intentions [35]. Nevertheless, other applications of CB1-RAN are being investigated. Most appealing seems to be the utilization of $\mathrm{CB} 1$ as a target in diseases with impaired motility such as IBS and chronic constipation. Our group showed that taranabant administered intraperitoneally in the doses of $0.1-3 \mathrm{mg} / \mathrm{kg}$ significantly increased GI transit in mice counted as a rate of the passage of the marker through the GI tract and the effect was dose-dependent; importantly, the stimulatory action of taranabant was also observed after oral administration in the dose of $3 \mathrm{mg} / \mathrm{kg}$ [5]. Moreover, the decrease in the total number of pain behaviors in acetic acidand mustard oil-induced mouse models of pain was seen after the administration of taranabant at the dose of $1 \mathrm{mg} / \mathrm{kg}$ i.p. and $3 \mathrm{mg} / \mathrm{kg}$ p.o. Thus, both features of IBS-C could be treated with CB1-blocking agents. Notably, our group noticed no 

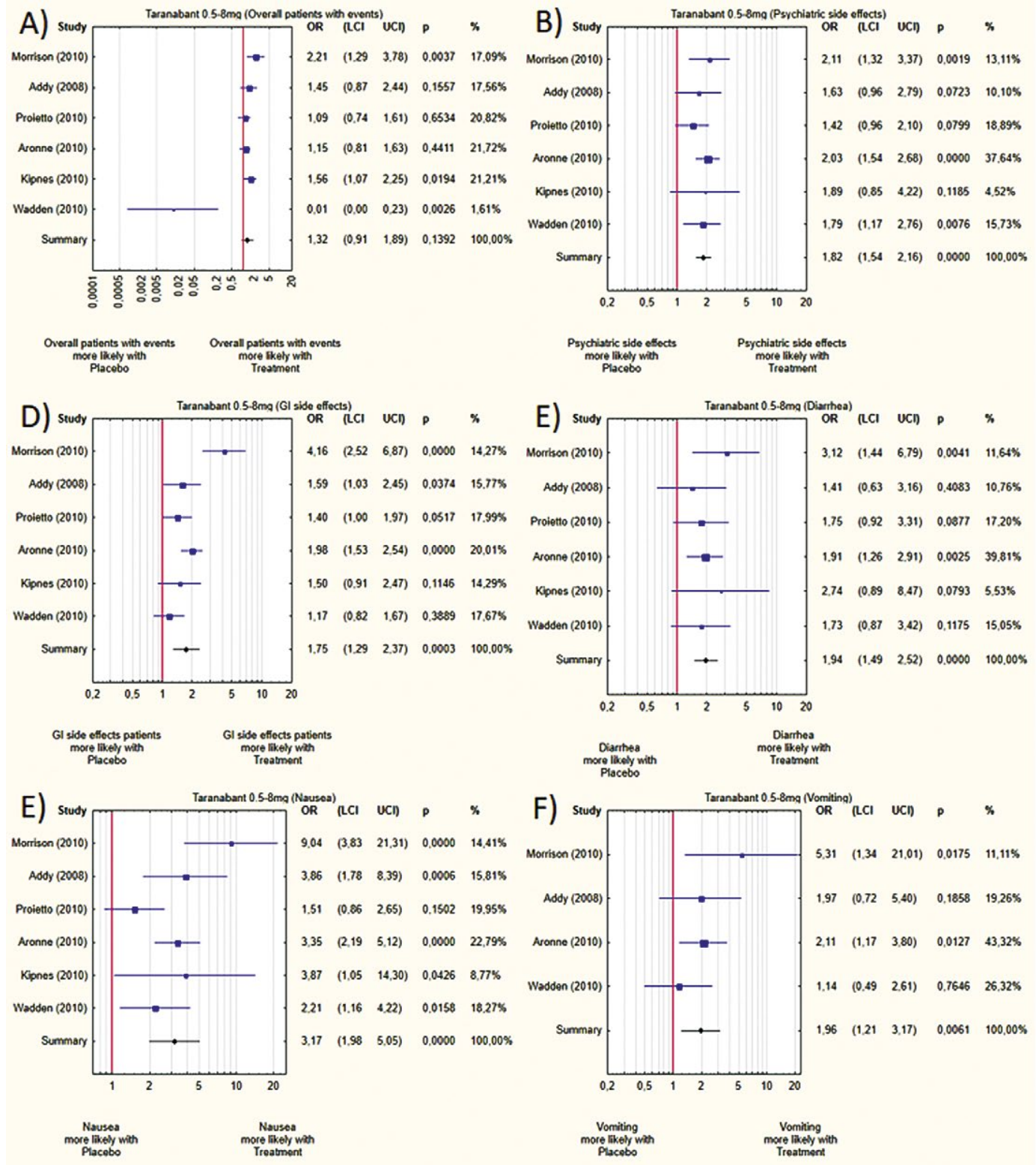

Fig. 5. Forest plots of adverse events reported in studies with taranabant vs. placebo. A) overall AEs, B) psychiatric AEs, C) GI AEs, D) diarrhea, E) nausea, F) vomiting. OR: odds ratio, LCI and UCI: lower and upper confidence interval

antidepressant-like activity in mice at these doses suggesting that low doses of taranabant does not induce undesired drug effects even after the systemic administration. As chronic constipation per se does not produce a significant pain or any mental issues, the results are only more encouraging. Indeed, studies already have addressed the endocannabinoids in the treatment of constipation. Bashahati et al. [36] found that by inhibiting diacylglycerol lipase- $\alpha$, enzyme involved in biosynthesis of $2-\mathrm{AG}$, fecal output in genetically constipated mouse strain is normalized.

The major strength of our meta-analysis is that it showed that CB1-RAN influenced GI motility in patients compared to a placebo and this effect was dose dependent for rimonabant. Results regarding specific GI AEs supports our hypothesis that blockage of CB1 may be regarded as a potent therapeutic target in constipation. These results might serve as a prelude for further human studies. It has to be noted that the chronic nature of IBS often needs a medium or long-term treatment thus a longer use of such drugs has to be determined. Our meta-analysis showed that the occurrence rate of rimonabantinduced AEs increased with the dose used ( $5 \mathrm{mg} \mathrm{OR}=1.26$, CI: $1.11-1.44$ vs. $20 \mathrm{mg} \mathrm{OR}=1.39 \mathrm{CI}: 1.25-1.55)$ and that GI AEs occurred more often than psychiatric AEs for both doses (1.14 vs 1.05 for $5 \mathrm{mg}$ of rimonabant and 2.05 vs 1.79 for 20 mg of rimonabant, respectively). Hence, it might be possible to acquire a dose at which CB1-RAN act on GI tract exclusively with a minimal action within the central nervous system. A more promising approach would be the development of peripherally restricted compounds since central CB1 action is not needed for the treatment of constipation and such compounds would be free of central psychiatric side effects.

Our meta-analysis has several limitations. The most prominent limitation refers to the discrepancies in the threshold of reporting the occurrence rate of AEs among the studies. The percentage of events occurring in the trials to be considered as an $\mathrm{AE}$ varied from 1 to $5 \%$. Also, some studies 
distinguished treatment with emerged AEs (TEAEs) and general AEs. We attempted to obtain the TEAEs rather than the general AEs but it was not always possible. However, we did not split the results in regard to the AEs reporting threshold as the assessment of trial methodologies was not our goal and it would have made the results illegible. The exclusion of one, large study [31] can be regarded as a major drawback, but we felt that this might have included incomplete data since the respective study was early terminated and aborted. However, the ORs for GI and psychiatric AEs were comparable between the results of meta-analysis and the excluded study [31]: $\mathrm{OR}=1.66,95 \% \mathrm{CI}: 1.55-1.77$ and $\mathrm{OR}=1.75,95 \% \mathrm{CI}: 1.64-1.87$, accordingly. Initially, we wanted to assess the AEs occurring in the taranabant users in relation to the dose used, but there were only a few (six) studies evaluating the efficacy of taranabant and the doses used were too sparse. We decided to consider all patients taking any dose of taranabant in each study as one group. Lastly, we acknowledge that our methodology lacks the opportunity to completely assess the patients and their symptoms which they reported across the studies. Namely, we do not know the overlap of patients' reports of specific AEs; for instance, if the patients with constipation also reported other AEs such as nausea, psychiatric events, etc. Addressing these issues would shed light on dose-effect relationships and how to avoid certain 'undesired effects'. Nonetheless, the possible connections between the reported AEs were not in the scope of our study and further studies including CB1-RAN must answer these questions.

\section{CONCLUSION}

The approach to target CB1 in the gut, namely in IBS-C or chronic constipation, seems a promising treatment option. The results of our meta-analysis supports recent reports on their motility effects from pre-clinical studies. Further clinical trials on the possible use of CB1 and the endocannabinoid system in the treatment of IBS-C or chronic constipation are warranted.

Conflicts of interest: The authors declare no conflict of interest.

Authors' contributions: A.F., M.S., J.F.: study design. A.F, M.W. N.F.: literature search. M.W statistical analysis. All the authors were involved in the writing of the manuscript and approved the final version.

Acknowledgements: This work was supported by a grant from the Medical University of Lodz (501/1-156-04/503-11-001 to J.F.).

Supplementary material: To access the supplementary material visit the online version of the J Gastrointestin Liver Dis at http://dx.doi. org/10.15403/jgld-265

\section{REFERENCES}

1. Lovell RM, Ford AC. Global Prevalence of and Risk Factors for Irritable Bowel Syndrome: A Meta-analysis. Clin Gastroenterol Hepatol 2012;10:712-721. doi:10.1016/j.cgh.2012.02.029

2. Drossman DA, Chang L, Chey WD, Kellow J, Tack J, Whitehead WE, The Rome IV Committees. Rome IV functional gastrointestinal disorders - disorders of gut-brain interaction. I. Raleigh, NC: The Rome Foundation; 2016.

3. Mosińska P, Salaga M, Fichna J. Novel investigational drugs for constipation-predominant irritable bowel syndrome: a review. Expert Opin Investig Drugs 2016;25:275-286. doi:10.1517/13543784.2016.11 42532

4. Sonu I, Triadafilopoulos G, Gardner JD. Persistent constipation and abdominal adverse events with newer treatments for constipation. BMJ Open Gastroenterol 2016;3:e000094. doi:10.1136/ bmjgast-2016-000094

5. Fichna J, Sibaev A, Sałaga M, Sobczak M, Storr M. The cannabinoid-1 receptor inverse agonist taranabant reduces abdominal pain and increases intestinal transit in mice. Neurogastroenterol Motil 2013;25:e550-e559. doi:10.1136/bmjgast-2016-000094

6. Sam AH, Salem V, Ghatei MA. Rimonabant:From RIO to Ban. J Obes 2011;2011:432607. doi:10.1155/2011/432607

7. Park JM, Choi MG, Cho YK, et al. Cannabinoid receptor 1 gene polymorphism and irritable bowel syndrome in the Korean population a hypothesis-generating study. J Clin Gastroenterol 2011;45:45-49. doi:10.1097/MCG.0b013e3181dd1573

8. Fichna J, Wood JT, Papanastasiou M, et al. Endocannabinoid and cannabinoid-like fatty acid amide levels correlate with pain-related symptoms in patients with IBS-D and IBS-C: a pilot study. PLoS One 2013;8:e85073. doi:10.1371/journal.pone.0085073

9 Esfandyari T, Camilleri M, Busciglio I, Burton D, Baxter K, Zinsmeister AR. Effects of a cannabinoid receptor agonist on colonic motor and sensory functions in humans: a randomized, placebo-controlled study. Am J Physiol Gastrointest Liver Physiol 2007;293:G137-G145. doi:10.1152/ajpgi.00565.2006

10. Lundh A, Gøtzsche PC. Recommendations by Cochrane Review Groups for assessment of the risk of bias in studies. BMC Med Res Methodo 2008;8:22. doi:10.1186/1471-2288-8-22

11. Higgins JP, Thompson SG, Deeks JJ, Altman DG. Measuring inconsistency in meta-analyses. Br Med J 2003;327:557-560. doi:10.1136/bmj.327.7414.557

12. Tang JL, Liu JL. Misleading funnel plot for detection of bias in meta-analysis. J Clin Epidemiol 2000;53:477-484. doi:10.1016/s08954356(99)00204-8

13. Després JP, Golay A, Sjöström L; Rimonabant in Obesity-Lipids Study Group. Effects of rimonabant on metabolic risk factors in overweight patients with dyslipidemia. N Engl J Med 2005;353:2121-2134 doi:10.1056/NEJMoa044537

14. Scheen AJ, Finer N, Hollander P, Jensen MD, Van Gaal LF; RIO-Diabetes Study Group. Efficacy and tolerability of rimonabant in overweight or obese patients with type 2 diabetes: a randomised controlled study. Lancet 2006;368:1660-1672. doi:10.1016/S0140-6736(06)69571-8

15. Pi-Sunyer FX, Aronne LJ, Heshmati HM, Devin J, Rosenstock J; RIONorth America Study Group. Effect of rimonabant, a cannabinoid-1 receptor blocker, on weight and cardiometabolic risk factors in overweight or obese patients - RIO-North America: a randomized clinical trial. JAMA 2006;295:761-775. doi:10.1001/jama.295.7.761

16. Robinson JD, Cinciripini PM, Karam-Hage M, et al. Pooled analysis of three randomized, double-blind, placebo controlled trials with rimonabant for smoking cessation. Addict Biol 2018;23:291-303. doi:10.1111/adb.12508

17. Van Gaal LF, Scheen AJ, Rissanen AM, et al. Long-term effect of CB1 blockade with rimonabant on cardiometabolic risk factors: Two year results from the RIO-Europe Study. Eur Heart J 2008;29:1761-1771. doi:10.1093/eurheartj/ehn076 
18. Nissen SE, Nicholls SJ, Wolski K, et al. Effect of rimonabant on progression of atherosclerosis in patients with abdominal obesity and coronary artery disease:the STRADIVARIUS randomized controlled trial. JAMA 2008;299:1547-1560. doi:10.1001/jama.299.13.1547

19. Soyka M, Koller G, Schmidt P, et al. Cannabinoid receptor 1 blocker rimonabant (SR 141716) for treatment of alcohol dependence:results from a placebo-controlled, double-blind trial. J Clin Psychopharmacol 2008;28:317-324. doi:10.1097/JCP.0b013e318172b8bc

20. Rosenstock J, Hollander P, Chevalier S, Iranmanesh A; SERENADE Study Group. SERENADE: The Study Evaluating Rimonabant Efficacy in Drug-naive Diabetic Patients: effects of monotherapy with rimonabant, the first selective CB1 receptor antagonist, on glycemic control, body weight, and lipid profile in drug-naive type 2 diabetes. Diabetes Care 2008;31:2169-2176. doi:10.2337/dc08-0386

21. Després JP, Ross R, Boka G, Alméras N, Lemieux I; ADAGIO-Lipids Investigators. Effect of rimonabant on the high-triglyceride/low-HDLcholesterol dyslipidemia, intraabdominal adiposity, and liver fat the ADAGIO-lipids trial. Arterioscler Thromb Vasc Biol 2009;29:416-423. doi:10.1161/ATVBAHA.108.176362

22. Hollander PA, Amod A, Litwak LE, Chaudhari U; ARPEGGIO Study Group. Effect of rimonabant on glycemic control in insulin-treated type 2 diabetes: the ARPEGGIO trial. Diabetes Care 2010;33:605-607. doi: $10.2337 /$ dc09-0455

23. O'Leary DH, Reuwer AQ, Nissen SE, et al. Effect of rimonabant on carotid intima-media thickness (CIMT) progression in patients with abdominal obesity and metabolic syndrome: the AUDITOR Trial. Heart 2011;97:1143-1150. doi:10.1136/hrt.2011.223446

24. Pataky Z, Gasteyger C, Ziegler O, Rissanen A, Hanotin C, Golay A Efficacy of rimonabant in obese patients with binge eating disorder. Exp Clin Endocrinol Diabetes 2013;121:20-26. doi:10.1055/s-0032-1329957

25. Addy C, Wright $\mathrm{H}$, Van Laere K, et al. The acyclic CB1R inverse agonist taranabant mediates weight loss by increasing energy expenditure and decreasing caloric intake. Cell Metab 2008;7:68-78. doi:10.1016/j. cmet.2007.11.012

26. Proietto J, Rissanen A, Harp JB, et al. A clinical trial assessing the safety and efficacy of the CB1R inverse agonist taranabant in obese and overweight patients: low-dose study. Int J Obes (Lond) 2010;34:12431254. doi:10.1038/ijo.2010.38
27. Aronne LJ, Tonstad S, Moreno M, et al. A clinical trial assessing the safety and efficacy of taranabant, a CB1R inverse agonist, in obese and overweight patients: a high-dose study. Int J Obes (Lond) 2010;34:919935. doi:10.1038/ijo.2010.21

28. Kipnes MS, Hollander P, Fujioka K, et al. A one-year study to assess the safety and efficacy of the CB1R inverse agonist taranabant in overweight an-year study to assess the safety and obese patients with type 2 diabetes. Diabetes Obes Metab 2010;12:517-531. doi:10.1111/j.14631326.2009.01188.x

29. Wadden TA, Fujioka K, Toubro S, et al. A randomized trial of lifestyle modification and taranabant for maintaining weight loss achieved with a low-calorie diet. Obesity 2010;18:2301-2310. doi:10.1038/ oby.2010.67

30. Morrison MF, Ceesay P, Gantz I, Kaufman KD, Lines CR. Randomized, controlled, double-blind trial of taranabant for smoking cessation. Psychopharmacology (Berl) 2010;209:245-253. doi:10.1007/s00213010-1790-2

31. Topol EJ, Bousser MG, Fox KA, et al. Rimonabant for prevention of cardiovascular events (CRESCENDO): A randomised, multicentre, placebo-controlled trial. Lancet 2010;376:517-523. doi:10.1016/S01406736(10)60935-X

32. Van Gaal LF, Rissanen AM, Scheen AJ, Ziegler O, Rössner S; RIOEurope Study Group. Effects of the cannabinoid-1 receptor blocker rimonabant on weight reduction and cardiovascular risk factors in overweight patients: 1-year experience from the RIO- Europe study. Lancet 2005;365:1389-1397. doi:10.1016/S0140-6736(05)66374-X

33. Izzo AA, Camilleri M. Emerging role of cannabinoids in gastrointestinal and liver diseases: basic and clinical aspects. Gut 2008;57:1140-1155. doi:10.1136/gut.2008.148791

34. Hornby PJ, Prouty SM. Involvement of cannabinoid receptors in gut motility and visceral perception. Br J Pharmacol 2004;141:1335-1345. doi:10.1038/sj.bjp.0705783

35. Shrestha N, Cuffe JSM, Hutchinson DS, et al. Peripheral modulation of the endocannabinoid system in metabolic disease. Drug Discov Today 2018;23:592-604. doi:10.1016/j.drudis.2018.01.029

36. Bashashati M, Nasser $Y$, Keenan CM, et al. Inhibiting endocannabinoid biosynthesis:a novel approach to the treatment of constipation. $\mathrm{Br}$ J Pharmacol 2015;172:3099-3111. doi:10.1111/bph.13114 

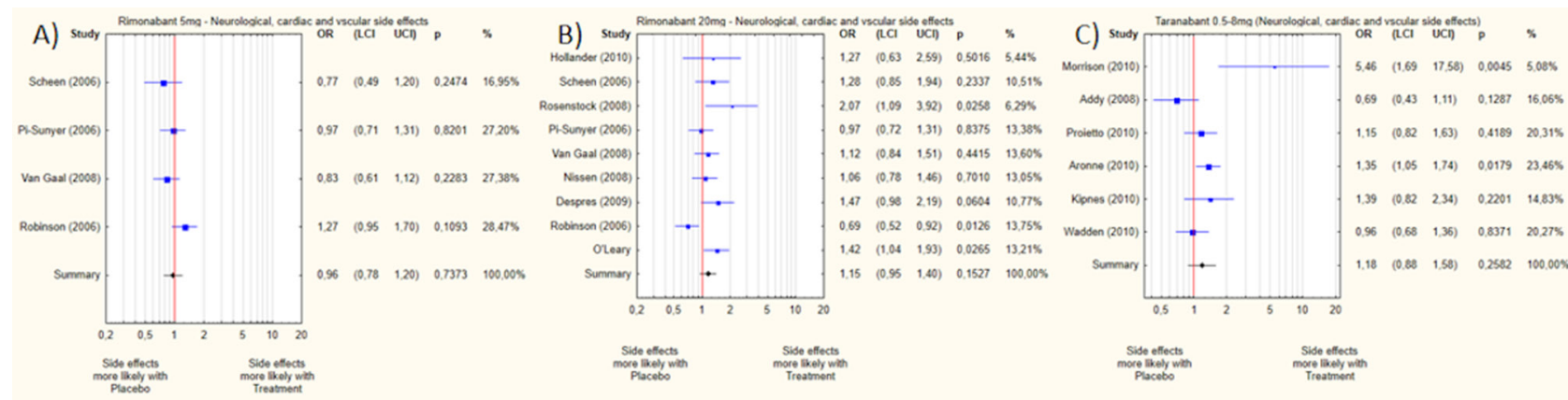

Supplementary Fig. 1. Forest plots of neurological, cardiac and vascular adverse events reported in studies with rimonabant $5 \mathrm{mg}(\mathrm{A}), 20 \mathrm{mg}$ (B) and taranabant (C) vs. placebo. OR: odds ratio, LCI and UCI: lower and upper confidence interval 